\title{
Choosing Ecotourism Destinations for Vacations: A Decision-Making Process
}

\author{
Eugene E. Ezebilo ${ }^{1}$ \\ ${ }^{1}$ Southern Swedish Forest Research Centre, Swedish University of Agricultural Sciences, Alnarp, Sweden \\ Correspondence: Eugene E. Ezebilo, Southern Swedish Forest Research Centre, Swedish University of \\ Agricultural Sciences, Box 49, 23053 Alnarp, Sweden. Tel: 46-4041-5197. E-mail: eugene.ezebilo@slu.se
}

Received: October 28, 2013 Accepted: November 21, 2013 Online Published: December 29, 2013

doi:10.5539/ass.v10n2p10

URL: http://dx.doi.org/10.5539/ass.v10n2p10

\begin{abstract}
Although ecotourism is fast growing industry information on travels to different ecotourism destinations are often not easily accessible. This paper reports reviews of literature on eco-tourists behaviour regarding choice of destination for ecotourism and factors influencing the choice. The importance of information in marketing of ecotourism and eco-tourists' satisfaction are discussed. The eco-tourists who are visiting a destination for the first time go through all stages in the decision-making process and extensive information search before choosing the destination to visit. Eco-tourists who have visited the destination in the past go through only some of the stages and limited information search. Eco-tourists' choice of an ecotourism destination are influenced by factors such as, the family, friends, societal values, preferences, safety and promotions related to the destination. Decision regarding re-visiting an ecotourism destination depends on the level of satisfaction that the eco-tourist experienced during his or her first time visit to the destination. Eco-tourists who are satisfied with the ecotourism destination during their first time visit are likely to re-visit the destination but those who are not satisfied are not likely to re-visit. For ecotourism managers to sustain the inflow of eco-tourists to different ecotourism destinations and revenue in the ecotourism industry it is important for the managers to strive towards meeting expectations of eco-tourists and make information regarding the destinations more accessible.
\end{abstract}

Keywords: consumer behaviour, choice, ecotourism, eco-tourists, decision-making, information search

\section{Introduction}

Ecotourism is a responsible travel to natural areas that conserves the environment and improves the well-being of local people (TIES, 1990). It involves visits to destinations where animals, plants and cultural heritage are the main attractions (Sadry, 2009; Ezebilo et al., 2010). Ecotourism accounts for a larger share of some countries gross domestic product e.g. Kenya, Madagascar, Nepal, Thailand and Malaysia (Isaacs, 2000). There are more than five million eco-tourists and most of them are from North America, Europe and Australia (Kamauro, 1996). Eco-tourists (i.e. visitors to ecotourism sites) often have varied demographic characteristics, personal backgrounds, preferences and motivations (Ezebilo et al., 2010). They can be classified based on motivations and preferences (Wight, 1996), environmental attitudes (Uysal et al., 1994), benefit segmentation (Palacio \& McCool, 1997), and cultural values (Blamey \& Braithwaite, 1997). Some literatures have also established a relationship between individual and group values, choice of product and eco-tourists behaviour (Lawson et al., 1996). There are many factors influencing ecotourism supply and demand (Assael, 1995; Sharpley, 1996). For example, eco-tourists tend to be more concerned about safety, security and anti-stress as a main consideration for travel (Jamieson, 2001; Klanarongran, 2001). In response to these demands most ecotourism destinations promote anti-stress-based tourism (Douglas et al., 2001). Some studies (Barke, 2004; Frochot, 2005) have shown that eco-tourists represent individuals with different values. Eco-tourists have different values and lifestyles, which may have effect on their demand e.g. most North American eco-tourists look for cultural and educational values (Plog, 1974; Hobson \& Ko, 1994), Singaporean eco-tourists seek for novelty and business (Swarbrooke \& Horner, 1999). Most European eco-tourists want nature to be prominent in their vacations (Poon, 1994). In order to meet the changing eco-tourist demands most countries which mostly depend on ecotourism for revenue have developed various ecotourism products such as spas, and natural-based resorts. For example, Thailand has developed many spas and anti-stress-based tourism sites to supply the eco-tourists demand (Circle of Asia, 2003). 
Eco-tourists are often faced with choice problems regarding decisions on destination to visit. Some of the decisions require intensive effort, i.e. extended problem-solving, and others require less effort, i.e. limited problem-solving (Solomon et al., 2006; Pride et al., 2012). In the extended problem-solving process the potential eco-tourist collects as much information as possible both from memory and from external sources such as from friends, internet and travel agencies. Each ecotourism destination alternatives are evaluated and ranked based on the eco-tourist's desired characteristics and the destination that corresponds to the eco-tourist's preference is chosen. For the case of limited problem-solving eco-tourists use simple decision such as price to choose a destination among alternatives. In order to become a successful manager in the ecotourism industry, one should be able to identify and understand eco-tourists' preferences (Anon, 1985). This will help ecotourism managers in planning and marketing of ecotourism products. Knowledge of eco-tourists preferences will help managers in provision of facilities required to attract tourists to ecotourism destination and in designing effective promotion strategy. The aim of this paper is to review the literature on eco-tourists' behaviour regarding choice of ecotourism destination and factors influencing the choice, as well as discuss the importance of information in marketing of ecotourism and eco-tourists' satisfaction.

\section{Method and Behavioural Learning Theory}

This paper is based on literature review. The articles used include text books, published articles in journals and grey literature related to consumer behaviour, ecotourism and factors influencing eco-tourists behaviour in the course of choosing destination for vacations. The articles were generated from google scholar, web of science and Scopus search engines.

Behavioural learning theory portend that people learn from their experiences and that people behavioural responses is related to their background and past experience (Pritchard, 2009). Behaviour that is followed by a reinforcing consequence will continue or strengthen, while behaviour that is followed by a punishing consequence will decrease or weaken (Lovell, 2012). For example, an eco-tourist who had good experience with a destination would be willing to re-visit the destination and vice-versa. Cognitive, emotional, environmental influences and past experience play an important role on how people perceive the world (Illeris, 2004; Omrod, 2012). According to conceptions of attribution (Kelly, 1963), i.e. all people are researchers; each individual have his or her own theory and they test their on hypothesis. An individual often test excuses than try to modify their thoughts (naïve theories, Olsson \& Ljunghill, 1997; Ezebilo, 2012). This is associated with individual's psychological theory, i.e. conscious and unconscious formed that influences an individual's life. In this paper this is referred to as "personal explanatory" theory (Emilsson \& Johnsson, 2007). It is assumed that learning process begins when the potential eco-tourist identifies some problems associated with ecotourism destination. Then the eco-tourist focuses on his or her personal explanatory theory and tries to explain reasons for the problems. In doing so the eco-tourist reflects on the problems associated with choice of destination and the probable solution to the problems. At the end of the reflections the eco-tourist develops new knowledge and personal theory regarding choice of ecotourism destination and this influences the eco-tourist's perceptions of the destination. Thus the perceptions are built around the eco-tourist's knowledge and experience (Morrison, 2004).

Eco-tourists' behaviour is influenced by the expectations of achieving desirable outcomes (Solomon et al., 2006; Ezebilo, 2011). They often choose the destination that will maximize their utility. Attitude is a predisposition to evaluate destination positively or negatively (Solomon et al., 2006). Attitudes are made up of beliefs and behavioural intentions. Some eco-tourists may develop some attitudes toward a destination based on whether the destination has security challenges. While some eco-tourists may develop an attitude toward a destination because of what the destination may say about them. Attitudes often help to guide choice of ecotourism destination e.g. a visit to the destination can be used to boost self-esteem. Choice of ecotourism destination may be based on non-compensatory rules, i.e. elimination of alternatives that are deficient in any criterion that the eco-tourist chose to use. The eco-tourist may also base his or her choice through compensatory rules, i.e. the eco-tourist considers each alternative's positive and negative points before making the final selection. If the alternative results in the eco-tourist's satisfaction over time, then, he or she may develop loyalty to the destination and encourages re-visit. Some eco-tourists may belong to or admire many different groups and are often influenced in their decisions on choice of destination by a desire to be accepted by others. According to Solomon et al. (2006) individuals often conform to the desires of other people basically for two reasons;

1) People model their behaviour on others because they take others' behaviour as evidence of the correct way to act.

2) Some people conform to certain behaviour to satisfy the expectations of others or to be accepted by the group that are affected by normative social influence. 


\section{Market Segmentation and Information Search in the Ecotourism Industry}

Market segmentation involves targeting a brand of product to specific group of consumers who share similar demand characteristics and preferences (Solomon et al., 2006). Because efforts are focused on meeting the demands and expectations of consumers of interest this can help improve effectiveness in marketing. Marketing of ecotourism involves identification of the characteristics of a desired group, appropriate advertising and careful crafting of the advertising message (Ryel \& Grasse, 1991). Like other industries the ecotourism industry does not have enough resources to supply the needs of all its market. Because of this limitation, the industry tends to target certain segment of the market based on the product they supply and eco-tourists' demands. Eco-tourists can be targeted on the basis of natural environment (Ryan et al., 2000). There may be differences between eco-tourists occupying an ecotourism environment. For example, some eco-tourists may only admire the natural environment without motivation beyond the immediate satisfaction of being there, whereas others may seek for specific benefits in reference to flora, fauna or cultural manifestations. The ecotourism marketer tends to target more of the group of eco-tourists who sought for specific benefits for visiting the ecotourism destination because they are more likely to revisit the destination. Ecotourism marketer may make use of demographic characteristics of eco-tourists such as age, gender, religion and income to target the ecotourism market. For example, a typical Taiwanese eco-tourist is a male and a recent graduate of the university (Tao et al., 2004). Furthermore, the ecotourism marketer may use the eco-tourists opinion to target the market. For example, eco-tourists who have eco-centric views favour more protectionist approach to management of national park, while those with anthropocentric views favour the transformation of the park (Kibicho, 2006). Eco-tourists can be targeted based on their attitudes, values and personalities (Silverberg et al., 1996). Eco-tourists visiting coastal wetlands of Taiwan were motivated to visit natural environments for physical health reasons (Kerstetter et al., 2004).

Ecotourism is an experience good, i.e. it is difficult to assess its qualities prior purchase. Hence, information is required from both eco-tourists and the ecotourism marketers (Williamson, 1985). Eco-tourists need information to choose destination and for onsite decisions such as selecting accommodations, transportation, activities, and tours (Gursoy \& Chen, 2000). Ecotourism is an information-oriented phenomenon (Schertler et al., 1995). Information increases the eco-tourists knowledge regarding a potential ecotourism destination and this helps the eco-tourists in choosing a destination (Werthner \& Klein, 1999). Thus, information is essential for the success of the ecotourism industry. Ecotourism industry relies on the exchange of information with eco-tourists to market their products. Eco-tourists depend on travel-related information for functional needs such as travel planning and other social, visual, entertainment, and creativity needs (Vogt \& Fesenmaier, 1998). Information search can be divided into internal search, i.e. scan in long-term memory for relevant product knowledge, external search, i.e. collection of information from the external world (Mullen \& Johnson, 1990). Information search may depend on the purpose of the trip (Fodness \& Murray, 1998), planning horizon (Gitelson \& Crompton, 1983), motivation (Vogt \& Fesenmaier, 1998) and level of involvement (Solomon et al., 2006). Many studies have shown that the major purpose of information search is to support decision-making (Bettman, 1979; Moorthy et al., 1997).

\section{Eco-Tourists Decision-Making Process}

Decision-making is an outcome of mental processes resulting in the choice of a product among several alternatives. Eco-tourists decision-making process can be seen from various perspectives such as psychological, i.e. decisions with regard to needs, preferences and value. The decision-making is a continuous process that may be influenced by the environment. Decision-making can also be regarded as a problem solving activity which ends when a solution to the problem has been achieved. According to the decision-making model (Solomon et al., 2006) the eco-tourist decision-making process comprises:

1) Need recognition i.e. the potential eco-tourist identifies the need to change environment. It can be stimulated by market information such as advertisement of the ecotourism destination. It can also be stimulated by relatives, friends and culture e.g. most European eco-tourists have the culture of travelling to ecotourism destinations during the summer.

2) Information search; once the need to travel is aroused the potential eco-tourist searches for information regarding ecotourism destinations. The information may be acquired from friends, internet, travel agencies and individual's memory.

3) Evaluation of the available ecotourism destinations; the potential eco-tourist makes an assessment of the available alternatives. He or she attempts to rank the potential destinations in order of preference.

4) Purchase decision; the eco-tourist chooses the most preferred ecotourism destination from the available alternatives. The choice of the destination is often determined by the criteria that the eco-tourist uses in the course of selection. The choice can also be influenced by price, friends, family and culture. 
5) Post purchase behaviour; if the eco-tourist is satisfied with his or her trip to an ecotourism destination the eco-tourist will likely re-visit the same destination.

Suffice is to say that, each eco-tourist segment will be different (Krippendorf, 1987). For example, backpackers may need a different level of recognition and different method of information search compared to mass tourists. Decision-making process can be classified according to the complexity of the process, i.e. extended, limited and habitual (Solomon et al., 2006). In extended problem-solving the eco-tourist collects information from external sources such as friends, internet and travel agents; they rank the available ecotourism destinations, eliminates destinations with undesirable characteristics and the most desired ecotourism destination is chosen (Solomon et al., 2006; Blackwell et al., 2001). Extended problem-solving may be used by the eco-tourists who are visiting an ecotourism destination for the first time. For the case of limited problem-solving, it does not require much effort in choosing an ecotourism destination. In this type of problem-solving the eco-tourist may not have much incentive to evaluate the available alternatives rigorously. The eco-tourist often makes use of internal search (memory) of information and may also use little external sources to update his or her knowledge on the ecotourism destination. Limited problem-solving may be used by eco-tourists who are re-visiting an ecotourism destination. Because they already have experience regarding the destination they may not need to put much effort in search for information with regards to the destination. Habitual problem-solving is related to decisions which eco-tourists make with little or no effort in searching for information. This includes the type of food to eat and whether to swim. The eco-tourist may implore this type of problem-solving technique at the ecotourism destination.

According to the decision-making model (Solomon et al., 2006), if eco-tourists are satisfied with an ecotourism destination, they may be more willing to re-visit the destination. This implies that eco-tourists satisfaction is crucial for a re-visit to an ecotourism destination (Hui \& Wan, 2006). Decision-making process for re-visit behaviour is different from that of the first time visit. First time visitors go through all stages in the decision making process before choosing the destination to visit. But re-visitors behaviour is characterized by shortening the stages, a limited information search and few or only one alternative. If satisfaction from the initial visit to an ecotourism destination results in a re-visit this may develop the eco-tourist's loyalty to a certain destination. On the other hand if the eco-tourist is dissatisfied with his or her initial trip to the destination, the eco-tourist will follow the extended problem-solving process for the next trip. Many studies have shown that there is a relationship between eco-tourist satisfaction and the intention to re-visit (Alegre \& Cladera, 2006; Chen \& Tsai, 2007). Petrick et al., (2001) found that satisfaction along with perceived value and past experience is a good predictor for the intention to re-visit entertainment travel destinations. A lot of studies have reported that re-visitors to ecotourism destination usually spend less time on information search and planning because they relied on their previous experience (Gursoy \& MacCleary, 2004; Woodside \& Dubelaar, 2002; Li et al., 2008; Kozak, 2001). Repeat visitation may offer a stable source of revenue for ecotourism destinations and also contributes to provision of information regarding the destination to potential eco-tourists (Pritchard, 2003). Repeat eco-tourist visitors may not be very sensitive to the price strategies of competing ecotourism destinations (Alegre \& Juaneda, 2006) and satisfied eco-tourists are likely to return (Oppermann, 2000). Re-visit behaviour is usually led by brand or product loyalty (Hawkins et al., 2004). The opinions and behaviour of other people such as relatives and friends may influence the potential eco-tourist choice of an ecotourism destination (Jang et al., 2007). For example, a family member may have different preferences for the different destinations. One of the most important tourism decision making and consumption units is the family (Kang \& Hsu, 2005). The family is the most influential social group. Thus, preferences for alternatives within the family unit may hinder re-visitation because the final choice of ecotourism destination is likely to be determined jointly (Van Raaij \& Francken, 1984).

\section{Discussion and Conclusions}

Choice of ecotourism destination is strongly linked to the amount of information available to the potential eco-tourists and their experience. Eco-tourists who do not have adequate information regarding the destination they intend to visit are likely to choose a destination that may not meet their expectations. This implies that it is important for potential eco-tourists to carry out an extensive information search related to the destination before choosing it. It is also important for potential eco-tourists to seek help from travel agencies and people who have visited the ecotourism destination. Ecotourism managers should strive to make information on different ecotourism destinations available to potential eco-tourists. This will help in bridging the gap between facilities that are available at different destinations and the expectation of eco-tourists.

Information plays an important role in efficient allocation of resources and for market to operate competitively (Nicholson, 2002). The mode and the extent of information search regarding an ecotourism destination will 
depend on the cost associated with the search and whether the individual is familiar with the destination. In a study of information search behaviour of tourists Gursoy and McCleary (2004) found that information search is influenced by costs, familiarity with the destination and previous visits to the destination. In many countries, access to information regarding benefits and costs of ecotourism to society is limited. Some ecosystem services provided by ecotourism sites are post-experience goods, i.e. their consumption does not necessarily reveal information to consumers. The information needed is expensive to gather and individuals may be unwilling to pay for it, and third parties may not have the incentive to provide the necessary information. Government intervention to reduce information asymmetry associated with post-experience goods is likely to be efficiency-enhancing because learning through individual action does not always occur. The long-term period over which management decisions take place implies the need for information concerning the future. When there is no adequate information it may delay potential eco-tourists from making information-based decisions regarding travels to ecotourism destinations.

Eco-tourists vary with respect to preferences, motivation, values and demography. Decision to visit an ecotourism destination are influenced by eco-tourists' preferences, relatives, friends, culture and advertisement. In a study on the comparison of first-time and repeat visitors Li et al. (2008) found that first-timers' behaviours are more travel oriented and are more active planners, while repeaters' behaviours are activity oriented and are more positive post-trip evaluations. Knowledge and quality of a destination motivate tourist expenditure; preference for quality and place attachment leads to a higher expenditure (Alegre \& Juaneda, 2006) and ecotourism destination image have direct and indirect effects on behavioural intentions and satisfaction (Chen \& Tsai, 2007). Information is of great importance with regard to marketing of ecotourism because the more information a potential eco-tourist have regarding a destination the greater would be the possibility of choosing the ecotourism destination. In a study of past vacation and the intentions to revisit Petrick et al. (2000) found that satisfaction and perceived value of a destination influences intentions to revisit. Family members have influence on choice of ecotourism destination to visit. Jang et al. (2007) found that each member of a couple reduced conflicts by adding some of other's alternative choice into their own choice set through discussion and then build the final choice set.

Eco-tourists who are visiting an ecotourism destination for the first time may require a longer time to make decision regarding choice of destination because 'first timers' often go through complex problem-solving technique. Eco-tourists who are re-visiting a destination often use less time in making decision because they already have some experience on the ecotourism destination. Sustenance of the ecotourism destinations depend on the patronage by eco-tourists. Thus it is important for ecotourism managers to have more understanding of eco-tourists preferences in order to package ecotourism to meet the expectations of eco-tourists. Future study regarding strategies to reduce costs associated with information search especially those related to travels to ecotourism destinations is advocated.

\section{References}

Alegre, J., \& Juaneda, C. (2006). Destination loyalty: Consumers' Economic Behaviour. Annals of Tourism Research, 33, 684-706. http://dx.doi.org/10.1016/j.annals.2006.03.014

Anon. (1985). AMA Board approves new marketing definition. Marketing Educator, 1.

Assael, H. (1995). Consumer behaviour and marketing action. International Thomson Publishing, Cincinnati, United States.

Barke, M. (2004). Rural tourism in Spain. International Journal of Tourism Research, 6, 137-149. http://dx.doi.org/10.1002/jtr.480

Bettman, J. R. (1979). Information processing theory of consumer choice. Boston: Addison-Wesley.

Blackwell, R., Miniard, P., \& Engel, J. (2001). Consumer Behaviour (9th ed.). Orlando: Harcourt, Inc., United States.

Blamey, R., \& Braithwaite, V. (1997). A social values segmentation of the potential ecotourism market. Journal of Sustainable Tourism, 5(1), 29-45. http://dx.doi.org/10.1080/09669589708667274

Chen, C., \& Tsai, D. (2007). How destination image and evaluative factors affect behavioural intentions? Tourism Management, 28, 1115-1122. http://dx.doi.org/10.1016/j.tourman.2006.07.007

Circle of Asia. (2003). Thailand Spa Guide and Directory. Retrieved March 1, 2003, from http://www.Spainthailand.com

Douglas, N., Douglas, N., \& Derrett, R. (Eds.). (2001). Special Interest Tourism, 356. John Wiley and Sons. 
Emilsson, U. M., \& Johnsson, E. (2007). Supervision of supervisors: On developing supervision in postgraduate education. Higher Education Research \& Development, 26(2), 163-179. http://dx.doi.org/10.1080/07294360701310797

Ezebilo, E. E. (2011). Local participation in forest and biodiversity conservation in a Nigerian rain forest. International Journal of Sustainable Development and World Ecology, 18(1), 42-47. http://dx.doi.org/10.1080/13504509.2011.544389

Ezebilo, E. E. (2012). Challenges in Postgraduate Studies: Assessments by Doctoral Students in a Swedish University. Higher Education Studies, 2(4), 49-57. http://dx.doi.org/10.5539/hes.v2n4p49

Ezebilo, E. E., Mattsson, L., \& Afolami, C. A. (2010). Economic value of ecotourism to local communities in the Nigerian rainforest zone. Journal of Sustainable Development, 3(1), 51-60.

Fodness, D., \& Murray, B. (1998). A typology of tourist information search strategies. Journal of Travel Research, 37, 108-119. http://dx.doi.org/10.1177/004728759803700202

Frochot, I. (2005). A benefit segmentation of tourists in rural areas: A Scottish perspective. Tourism Management, 26, 335-346. http://dx.doi.org/10.1016/j.tourman.2003.11.016

Gitelson, R., \& Crompton, J. (1983). The planning horizons and sources of information used by pleasure vacationers. Journal of Travel Research, 21, 2-7. http://dx.doi.org/10.1177/004728758302100301

Gursoy, D., \& Chen, J. (2000). Competitive analysis of cross cultural information search behaviour. Tourism Management, 21, 583-590. http://dx.doi.org/10.1016/S0261-5177(00)00005-4

Gursoy, D., \& McCleary, K. W. (2004). An integrative model of tourists' information search behaviour. Annals of Tourism Research, 31(2), 353-373. http://dx.doi.org/10.1016/j.annals.2003.12.004

Hawkins, D., Best, R., \& Coney, K. (2004). Consumer behaviour: Building marketing strategy (9th ed.). New York: McGraw-Hill.

Hobson, J. S. P., \& Ko, G. (1994). Tourism and politics: The implications of change and sovereignty on the future development of Hong Kong's Tourism Industry. Journal of Travel Research, 32(4), 2-8. http://dx.doi.org/10.1177/004728759403200401

Hui, T. K., \& Wan, D. (2006). Predictive Model for Repeat Visitors to Singapore. Advances in Hospitality and Leisure, 2, 107-121. http://dx.doi.org/10.1016/S1745-3542(05)02006-0

Illeris, K. (2004). The three dimensions of learning. Malabar, Fla: Krieger Publication Company.

Isaacs, J. C. (2000). The limited potential of ecotourism to contribute to wildlife conservation. The Ecologist, 28(1), 61-69.

Jamieson, W. (2001). Interpretation and Tourism. In J. Walter (Ed.), Community Tourism Destination Management: Principles and Practices. Saengsawang World Press, Thailand.

Jang, H., Lee, S., Lee, S., \& Hong, S. (2007). Expanding the individual choice-sets model to couples' honeymoon destination selection process. Tourism Management, 28, 1299-1314. http://dx.doi.org/10.1016/j.tourman.2006.11.008

Kamauro, O. (1996). Ecotourism: Suicide or Development? Voices from Africa: Sustainable Development. U.N. Non-Governmental Liaison Service.

Kang, S., \& Hsu, C. (2005). Dyadic consensus on family vacation destination selection. Tourism Management, 26, 571-582. http://dx.doi.org/10.1016/j.tourman.2004.01.002

Kelly, G. A. (1963). A theory of personality: The psychology of personal constructs. New York: W.W. Norton.

Kerstetter, D., \& Cho, M. H. (2004). Prior knowledge, credibility and information search. Annals of Tourism Research, 31(4), 961-985. http://dx.doi.org/10.1016/j.annals.2004.04.002

Kibicho, W. (2006). Tourists to Amboseli National Park: A factor-cluster segmentation analysis. Journal of Vacation Marketing, 12(3), 218-231. http://dx.doi.org/10.1177/1356766706064618

Klanarongran, P. (2001). Community Participation in the Royal Development Projects. In J. Walter (Ed.), Community Tourism Destination Management: Principles and Practices. Saengsawang World Press, Thailand.

Kozak, M. (2001). Repeaters' behaviour at two distinct destinations. Annals of Tourism Research, 28, 784-807. http://dx.doi.org/10.1016/S0160-7383(00)00078-5 
Krippendorf, J. (1987). The Holidaymakers: Understanding the Impacts of Leisure and Travel. Heinemann, London.

Lawson, R., Tidwell, P., Rainbird, P., Loudon, D., \& Bitta, A. D. (1996). Consumer behaviour in Australia and New Zealand. Sydney: McGraw-Hill.

Li, X., Cheng, C., Kim, H., \& Petrick, J. F. (2008). A systematic comparison of first-time and repeat visitors via a $\begin{array}{lllll}\text { two-phase online } & \text { survey. } & \text { Tourism } & \text { Management, } & \text { 29, } 293 .\end{array}$ http://dx.doi.org/10.1016/j.tourman.2007.03.010

Lovell, A. (2012). Behavioural learning theories. In A. McIntosh, J. Gidman, \& E. M. Whithead (Eds.), Key concepts in health education. SAGE Publications Ltd.

Moorthy, S., Ratchford, B. T., \& Talukdar, D. (1997). Consumer information search revisited: Theory and empirical analysis. Journal of Consumer Research, 23(4), 263-277. http://dx.doi.org/10.1086/209482

Morrison, J. (2004). Where now for problem-based learning? The Lancet, 363, 174. http://dx.doi.org/10.1016/S0140-6736(03)15298-1

Mullen, B., \& Johnson, C. (1990). The psychology of consumer behaviour. Hillsdale: Lawrence Erlbaum.

Nicholson, W. (2002). Microeconomic theory: Basic principles and extensions. South-Western, Thomson Learning.

Olsson, E., \& Ljunghill, J. (1997). The practioner and 'Naïve Theory' in Intervention Processes of Social Work. British Journal of Social Work, 27, 931-950. http://dx.doi.org/10.1093/oxfordjournals.bjsw.a011286

Omrod, J. (2012). Human learning. Boston: Pearson.

Oppermann, M. (2000). Tourism Destination Loyalty. Journal of Tourism Research, 39, 78-84.

Palacio, V., \& McCool, S. (1997). Identifying ecotourists in Belize through benefit segmentation: A preliminary analysis. Journal of Sustainable Tourism, 5, 234-243. http://dx.doi.org/10.1080/09669589708667288

Petrick, J. F., Moralis, D. D., \& Norman, W. C. (2001). An examination of the determinants of entertainment vacationers' intentions to revisit. Journal of Travel Research, 40(1), 41-48. http://dx.doi.org/10.1177/004728750104000106

Plog, S. C. (1974). Why destination areas rise and fall in popularity. The Cornell Hotel and Restaurant Administration quaterly, 14(2), 55-58. http://dx.doi.org/10.1177/001088047401400409

Poon, A. (1994). Tourism, Technology and Competitive Strategies. Cab International.

Pride, W. M., Ferrel, O. C., Lukas, B. A., Schembri, S., \& Niininen, O. (2012). Marketin Principles. Cengage Learning, Sydney, Australia.

Pritchard, A. (2009). Ways of Learning: Learning Theories and Learning Styles in the Classroom. Routledge, Oxon, U.K.

Pritchard, M. (2003). The attitudinal and behavioural consequences of destination performance. Tourism Analysis, 8, 61-73. http://dx.doi.org/10.3727/108354203108750175

Ryan, B. F., Katzfey, J. J., Abbs, D. J., Jakob, C., Lohmann, U., Rockel, B., .. Yau, M. K. (2000). Simulation of a cold front by cloud-resolving, limited-area, and large scale models model evaluation using in-situ and satellite observations. Monthly Weather Review, 128, 3218-3235. http://dx.doi.org/10.1175/1520-0493(2000)128<3218:SOACFB $>2.0 . C O ; 2$

Ryel, R., \& Grasse, T. (1991). Marketing ecotourism: Attracting the elusive ecotourist. In Whelan (Ed.), Nature Tourism: Managing for the environment. Island Press, Washington DC.

Sadry, B. N. (2009). Fundamentals of Geotourism: With a special emphasis on Iran. Samt Organization publishers, Tehran, Iran.

Schertler, W., Schmid, B., Tjoa, A. M., \& Werthner, H. (1995). Information andcommunication technologies in tourism. New York: Springer, Wien. http://dx.doi.org/10.1007/978-3-7091-7596-5

Sharpley, R. (1996). Tourism and consumer culture in postmodern society. In M. Robinson, N. Evans, \& P. Callaghan (Eds.), Proceedings of the Tourism and Culture: Towards the $21^{\text {st }}$ Century Conference (pp. 203-215). Centre for Travel and Tourism/Business Education Publishers, Sunderland.

Silverberg, K. E., Backman, S. J., \& Backman, K. F. (1996). A preliminary investigation into the psychographics of nature-based travelers to south eastern United States. Journal of Travel Research, 35(2), 19-28. 
http://dx.doi.org/10.1177/004728759603500204

Solomon, M., Bamossy, G., Askegaard, S., \& Hogg, M. K. (2006). Consumer Behaviour-A European Perspective. Prentice Hall, New Jersey, USA.

Swarbrooke, J., \& Horner, S. (1999). Consumer Behaviour in Tourism, Butterworth-Heinemann. Great Britain.

Tao, C., Eagles, P. F. J., \& Smith, S. L. J. (2004). Profiling Taiwanese ecotourists using a self-definition approach. Journal of Sustainable Tourism, 12(2), 149-168. http://dx.doi.org/10.1080/09669580408667230

TIES (The International Ecotourism Society). (n. d.). Retrieved September 10, 2009, from $\mathrm{http} / / / \mathrm{www}$. ecotourism.org/site/c.orLQKXPCLmF/b.4835303/k.BEB9/What_is_Ecotourism_The_Internati onal_Ecotourism_Society.htm

Uysal, M., Jurowski, C., Noe, E., \& McDonald, C. (1994). Environmental attitude by tripand visitor characteristics. Tourism Management, 15, 284-294. http://dx.doi.org/10.1016/0261-5177(94)90046-9

Van Raaij, W., \& Francken, D. (1984). Vacation decisions, activities and satisfactions. Annals of Tourism Research, 11, 101-112. http://dx.doi.org/10.1016/0160-7383(84)90098-7

Vogt, C. A., \& Fesenmaier, D. R. (1998). Expanding the functional information search model. Annals of Tourism Research, 25(3), 551-578. http://dx.doi.org/10.1016/S0160-7383(98)00010-3

Werthner, H., \& Klein, S. (1999). Information technology and tourism-A challenging relationship. New York: Springer, Wien. http://dx.doi.org/10.1007/978-3-7091-6363-4

Wight, P. (1996). North American ecotourism markets: Motivations, preferences and destinations. Journal of Travel Research, 35(1), 3-10. http://dx.doi.org/10.1177/004728759603500102

Williamson, O. E. (1985). A history of computing technology. Englewood Cliffs, NJ: Prentice Hall.

Woodside, A. G., \& Dubelaar, C. (2002). A general theory of tourism consumption systems: A conceptual framework and an empirical exploration. Journal of Travel Research, 41(2), 120-132. http://dx.doi.org/10.1177/004728702237412

\section{Copyrights}

Copyright for this article is retained by the author(s), with first publication rights granted to the journal.

This is an open-access article distributed under the terms and conditions of the Creative Commons Attribution license (http://creativecommons.org/licenses/by/3.0/). 